\title{
Cultivation Of Bsf (Black Soldier Fly) As Fish Feed In Sukamaju District, Binjai Barat Sub-District, Binjai City
}

\author{
Achmad Sadeli $^{1^{*}}$, Adrian Hilman ${ }^{2,5}$, Lukman Hakim $^{3,5}$, Delima Lailan Sari Nasution ${ }^{4}$ dan Azhari ${ }^{3,5}$ \\ ${ }^{1}$ Animal Husbandry Study Program, Faculty of Agriculture, Universitas Sumatera Utara, Medan, \\ Indonesia \\ ${ }^{2}$ Food Science and Technology Study Program, Faculty of Agriculture, Universitas Sumatera Utara, \\ Medan, Indonesia \\ ${ }^{3}$ Department of Physics, Faculty of Mathematics and Natural Sciences, Universitas Sumatera Utara, \\ Medan, Indonesia \\ ${ }^{4}$ Agricultural Engineering Study Program, Faculty of Agriculture, Universitas Sumatera Utara, \\ Medan, Indonesia \\ ${ }^{5}$ Integrated Implementing Unit of Integrated Research Laboratory, Universitas Sumatera Utara, \\ Medan, Indonesia
}

*Coresponding Author: achmadsadeli@usu.ac.id

\begin{abstract}
his activity was conducted in July and November 2020. Partners of this activity is a freshwater fish farmer community located on Jalan Gatot Subroto no. LK 336 IV, Sukamaju, Binjai Barat Distirct, Binjai, Sumatera Utara. The main problems faced by partners are 1) Farmers have difficulty in providing fish feed in the form of worms 2) The price of worms continues to increase, so it is difficult for breeders to provide good nutrition 3) Community do not yet know what it flies BSF (Black Soldier Fly) 4) The community does not yet know how to cultivate BSF 5) The community does not know that BSF Maggot is a high protein feed. The purpose of implementing this activity is 1) so that farmers get a replacement feed worm 2) Farmers can get fish feed with good nutrient and reasonably priced 3) BSF Maggot cultivation training, so farmers know 4) as a source of increasing income for freshwater fish farmers. The output target to be achieved from this activity program is that farmers can cultivate and use BSF as freshwater fish feed. Output details of the program produced include: 1) training and assistance services for BSF Maggot cultivation 2) Video Activities 3) Scientific articles about mentoring cultivating devotion Maggot BSF. BSF extension and cultivation training activities have been carried out well, and have resulted in video activities on YouTube and also publications in online mass media. The conclusion of this activity partners know the advantages of BSF and can cultivate BSF properly.
\end{abstract}

Keyword: BSF (Black Soldier Fly), Freshwater Fish Farmers

\begin{abstract}
Abstrak
Kegiatan ini dilaksanakan pada bulan Juli sampai November 2020. Mitra kegiatan ini merupakan komunitas peternak ikan air tawar yang terletak di Jalan Gatot Subroto no. 336 LK IV, Kelurahan Sukamaju, Kecamatan Binjai Barat, Kota Binjai, Sumatera Utara. Permasalahan utama yang dihadapi mitra adalah 1) Peternak kesulitan dalam penyediaan pakan ikan berupa cacing 2) Harga cacing terus meningkat sehingga peternak kesulitan memberi pakan dengan nutrisi yang baik 3) Masyarakat belum mengenal ap aitu lalat BSF (Black Soldier Fly) 4) Masyarakat belum tahu cara membudidayakan BSF 5) Masyarakat belum mengetahui Maggot BSF merupakan pakan berprotein tinggi. Tujuan dari pelaksanaan kegiatan ini adalah 1) agar peternak mendapatkan pakan pengganti cacing 2) Peternak dapat mendapatkan pakan ikan dengan nutrient baik dan harga terjangkau 3) pelatihan budidaya Maggot BSF, agar peternak mengetahui 4) sebagai sumber peningkatan pendapatan peternak ikan air tawar. Target luaran yang ingin dicapai dari program kegiatan ini adalah peternak dapat membudidayakan dan memanfaatkan BSF sebagai pakan ikan air tawar. Rincian luaran program yang dihasilkan meliputi: 1) jasa pelatihan dan pendampingan pembudidayaan Maggot BSF 2) Video kegiatan 3) Artikel ilmiah pengabdian tentang pendampingan pembudidayaan Maggot BSF. Kegiatan penyuluhan dan pelatihan budidaya BSF telah dilaksanakan dengan baik, dan telah menghasilkan video kegiatan pada youtube dan juga publikasi pada media massa online. Kesimpulan dari kegiatan ini mitra mengetahui keunggulan BSF dan dapat membudidayakan BSF dengan baik dan benar.
\end{abstract}

Kata Kunci: BSF (Black Soldier Fly), Peternak Ikan Air Tawar 


\section{PENDAHULUAN (INTRODUCTION)}

Kecamatan Binjai Barat merupakan salah satu kecamatan di Kota Binjai yang memiliki enam (6) kelurahan yaitu Sukamaju, Sukaramai, Payaroba, Bandar Senembah, Limau Mungkur dan Limau Sundai. Kecamatan Binjai Barat memiliki ketinggian rata-rata 30 meter diatas permukaan laut dengan luas wilayah berupa darat seluas $10,86 \mathrm{~km} 2$.

Salah satu kelurahan di Kecamatan Binjai Barat adalah Kelurahan Sukamaju, dimana Kelurahan Sukamaju memiliki luas wilayah 1,43 km2. Kelurahan Sukamaju kecamatan Binjai Barat kota Binjai dipimpin oleh seorang Lurah bernama Muhammad Fauzi, S. Ip. Kelurahan ini memiliki tujuh (7) lingkungan. Pada lingkungan IV dan V merupakan lingkungan dimana ada komunitas masyarakat yang bergerak di bidang perikanan yaitu budidaya ikan air tawar. Komunitas masyarakat di lingkungan ini telah lama beternak ikan air tawar.

Pada pengabdian masyarakat ini, Tim pelaksana memilih komunitas peternak ikan air tawar yang terletak di Jalan Gatot Subroto no.336 LK IV, Kelurahan Sukamaju, Kecamatan Binjai Barat, Kota Binjai, Sumatera Utara. Pengabdian ini dilaksanakan dengan memanfaatkan limbah yang berada disekitar lokasi untuk dijadikan media pertumbuhan Maggot BSF. Berdasarkan pengamatan tim pelaksana kegiatan komunitas masyarakat peternak ikan air tawar ini meliputi pembenihan dan pembesaran sehingga sangat dibutuhkan pakan ikan dengan kualitas tinggi dan harga terjangkau agar dapat meningkatkan pendapatan peternak ikan air tawar tersebut. Peternakan ikan air tawar ini didirikan di atas lahan pekarangan rumah sebagai bentuk pemanfaatan lahan di tengah sempitnya lahan-lahan yang tersedia akibat pembangunan, komunitas ini di pimpin oleh bapak Suwanto.

Berdasarkan pengamatan yang telah dilaksanakan maka tim pelaksana merumuskan beberapa permasalahan yang dihadapi peternak ikan air tawar di Kelurahan Sukamaju Kecamatan Binjai Barat Kota Binjai sebagai berikut :

1. Peternak kesulitan dalam penyediaan pakan ikan berupa cacing.

2. Harga cacing terus meningkat sehingga peternak kesulitan memberi pakan dengan nutrisi yang baik.

3. Masyarakat belum mengenal apa itu lalat BSF (Black Soldier Fly)

4. Masyarakat belum tahu cara membudidayakan BSF (Black Soldier Fly)

5. Masyarakat belum mengetahui Maggot BSF (Black Soldier Fly) merupakan Pakan berprotein tinggi.

\section{METODE PELAKSANAAN (METHODS)}

Metode pendekatan yang dilakukan dalam mengatasi permasalahan mitra setelah dilakukan identifikasi masalah yang terjadi di komunitas peternak ikan air tawar di Kelurahan Sukamaju Kecamatan Binjai Barat Kota Binjai. Permasalahan yang sudah terindentifikasi kemudian dicarikan penyelesaian dalam bentuk program kegiatan dengan merujuk pada pendekatan iptek. Pendekatan iptek yang dilakukan kepada masyarakat (peternak) melalui beberapa kegiatan seperti memotivasi, pelatihan, pembuatan produk dan pendampingan. Pendekatan iptek yang diberikan adalah pemanfaatan Maggot BSF sebagai pakan ikan air tawar. Pendekatan tersebut diharapkan agar Maggot BSF yang memiliki kandungan protein dapat dimanfaatkan sebagai pakan ikan air tawar.

Rencana kegiatan yang akan dilakukan untuk menyelesaikan masalah dilakukan sesuai dengan kebutuhan mitra kegiatan pengabdian, hal ini diperlukan agar terjadi partisipasi aktif dari mitra dalam kegiatan. Evaluasi dilakukan setiap kali pelaksanaan kegiatan dan reguler setiap awal bulan selama program ini. Apabila didapatkan permasalahan langsung dilakukan tindakan perbaikan. Evaluasi yang dilakukan direkam dengan baik dan secara tertulis. Di akhir kegiatan dilakukan evaluasi secara keseluruhan untuk mengetahui ketercapaian seluruh kegiatan yang telah dilaksanakan. 


\section{HASIL DAN PEMBAHASAN (RESULT AND DISCUSSION)}

Kegiatan pengabdian masyarakat ini telah dilaksanakan sesuai dengan yang direncanakan dan memberikan dampak positif kepada mitra. Hal ini dapat dilihat dengan mulai banyaknya anggota koperasi yang memulai menbudidayakan lalat BSF dan juga sudah ada yang mencoba memberikan BSF sebagai pakan ikan mereka. Kegiatan dilaksanakan sebagai berikut :

\section{1. Persiapan dan Perencanaan Kegiatan}

Kegiatan persiapan dilakukan dengan cara audiensi terlebih dahulu kepada mitra dan mencari tahu permasalahan pada mitra. Setelah permasalahan diketahui tim pengabdian merancang solusi yang akan diberikan kepada mitra dan juga membuat proposal kegiatan untuk diajukan kepada Lembaga Pengabdian Kepada Masyarakat. Setelah proposal disetujui tim kembali berkoordinasi dengan mitra untuk menyampaikan rencana kegiatan yang akan dilaksanakan dan juga hak dan kewajiban dari kedua belah pihak, selain itu tim pengabdian meminta peran aktif dan komitmen untuk menyukseskan kegiatan pengabdian tersebut.

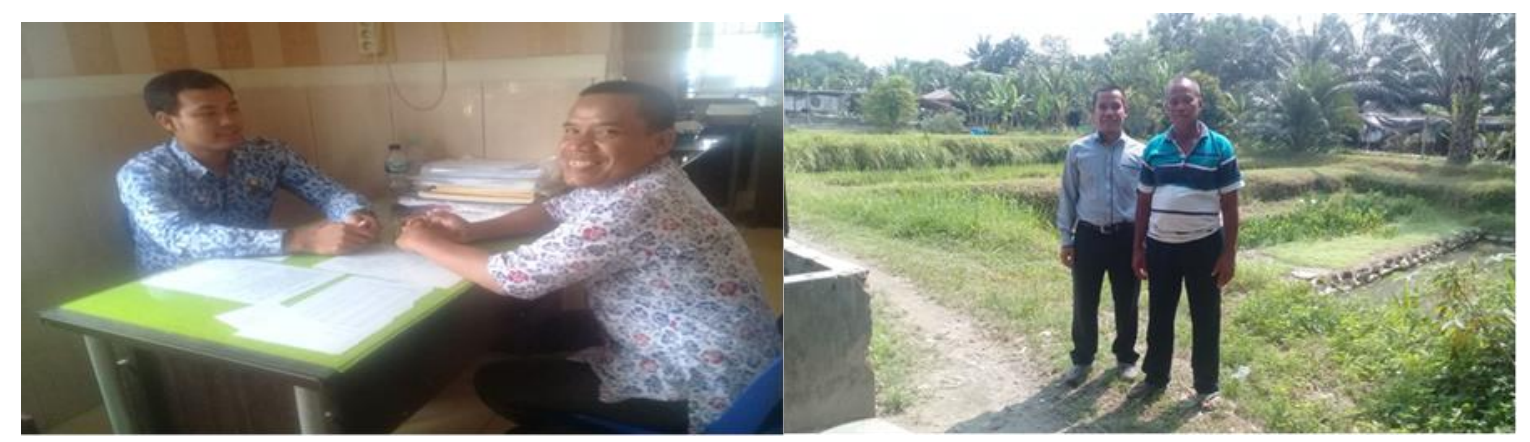

Gambar 3.1. Audiensi Tim Pengabdian Masyarakat dengan Lurah Kelurahan Sukamaju dan Peternak Ikan Air Tawar

\section{Penyuluhan Budidaya BSF (Black Soldier Fly)}

Penyuluhan budidaya BSF dilakukan sebanyak 2 kali yaitu pada tanggal 24 Oktober 2020. Pelatihan dilaksanakan di Koperasi Produsen Perikanan Budidaya Mina Sejahtera, Kelurahan Sukamaju Kecamatan Binjai Barat Kota Binjai. Mitra yang terdiri dari ketua dan anggota berkumpul di koperasi mengikuti penyuluhan dan pelatihan budidaya BSF. Pada kegiatan pertama dilakukan pemaparan keunggulan dan potensi BSF sebagai pakan ikan air tawar.

BSF bukan merupakan lalat hama atau vector penyakit sehingga sangat aman untuk dikembangkan, salah satu kelebihannya yang paling menonjol sehingga sangat layak dijadikan pakan ternak atau ikan adalah kandungan proteinnya yang sangat tinggi bisa mencapai kurang lebih $40 \%$ seperti yang dilaporkan Wardhana (2016), yang menyatakan kandungan nutrient larva prepupa yang dipelihara pada media BIS pada umur 25 hari mencapai $45,87 \%$ bahkan ketika umur 5 hari mencapai $61,42 \%$. 
Achmad, et al Cultivation Of Bsf (Black Soldier Fly) As Fish Feed In Sukamaju District, Binjai Barat SubDistrict, Binjai City
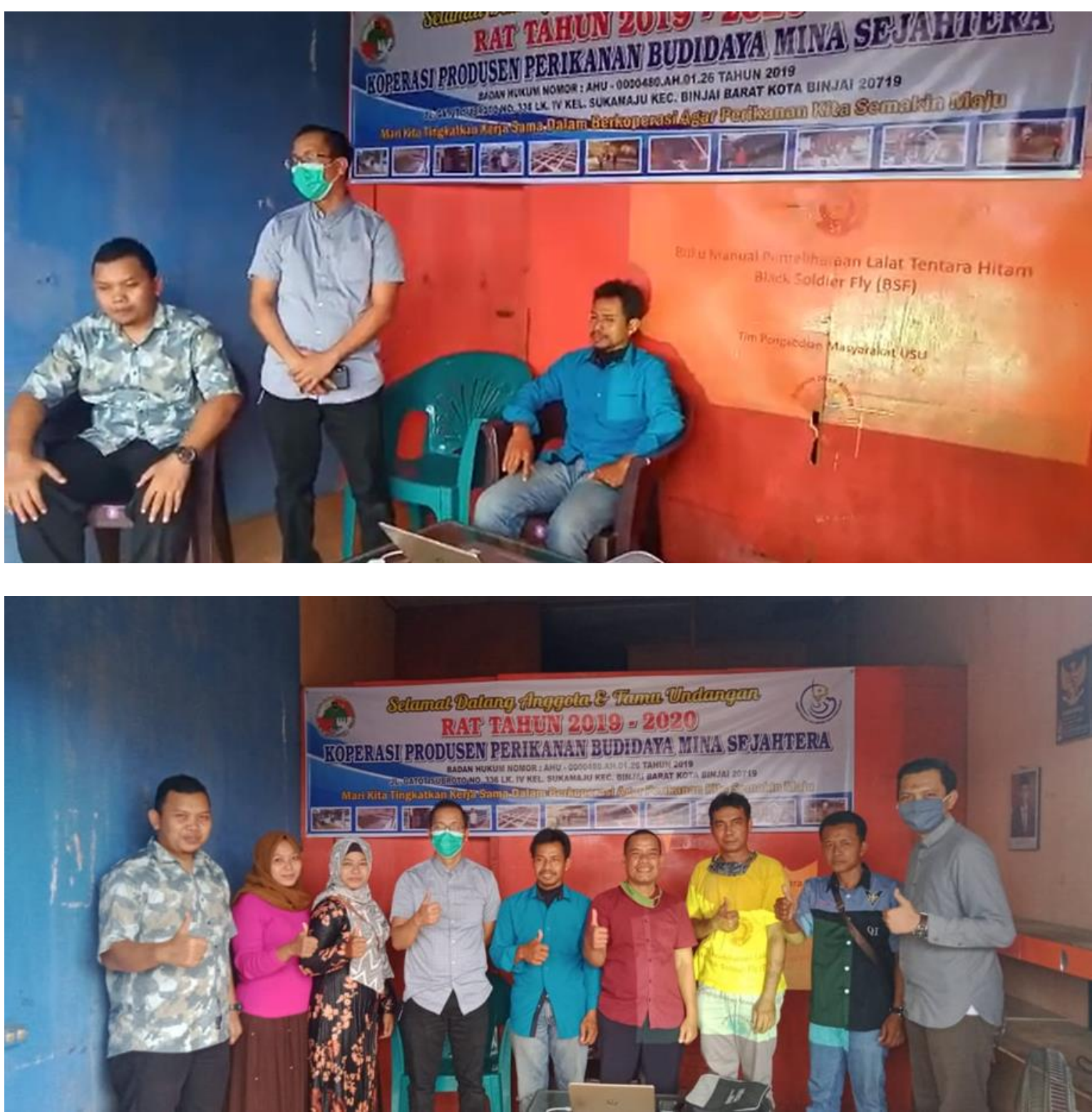

Gambar 3. 2. Penyuluhan Budidaya BSF (Black Soldier Fly)

Oleh karena itu tim pengabdian menganjurkan peternak untuk dapat memanfaatkan BSF sebagai sumber protein alternatif budidaya ikan air tawar. Karena seperti kita ketahui pakan sumber protein dilapangan harganya cukup tinggi, dilain sisi pakan merupakan pengeluaran terbesar dari suatu usaha peternakan atau perikanan dimana bisa mencapai $\quad 70 \%$ dari total produksi secara keseluruhan sehingga dengan pemanfaatan BSF ini dapat menekan biaya produksi dan meningkatakan keuntungan peternak ikan air tawar.

\section{Pelatihan Budidaya BSF (Black Soldier Fly)}

Pelatihan budidaya BSF dilakukan di Koperasi Produsen Perikanan Budidaya Mina Sejahtera, Kelurahan Sukamaju Kecamatan Binjai Barat Kota Binjai pada tanggal 7 November 2020. BSF memiliki siklus hidup 40-43 hari mulai dari sampai menjadi lalat dewasa tergantung dari lingkungan dan media pakan yang diberikan. Seperti Wardhana (2016) yang menggunakan bungkil inti sawit 
sebagai media maggot. Tim pengabdian disini memberikan pelatihan dengan memanfaatkan kombinasi dedak dan bungkil inti sawit dengan persentase $50 \%$ dedak, $25 \%$ tepung jagung dan 25 $\%$ bungkil inti sawit kemudian dicampur dengan campuran molases, EM4 dan air sampai kelembaban kurang lebih $60 \%$.

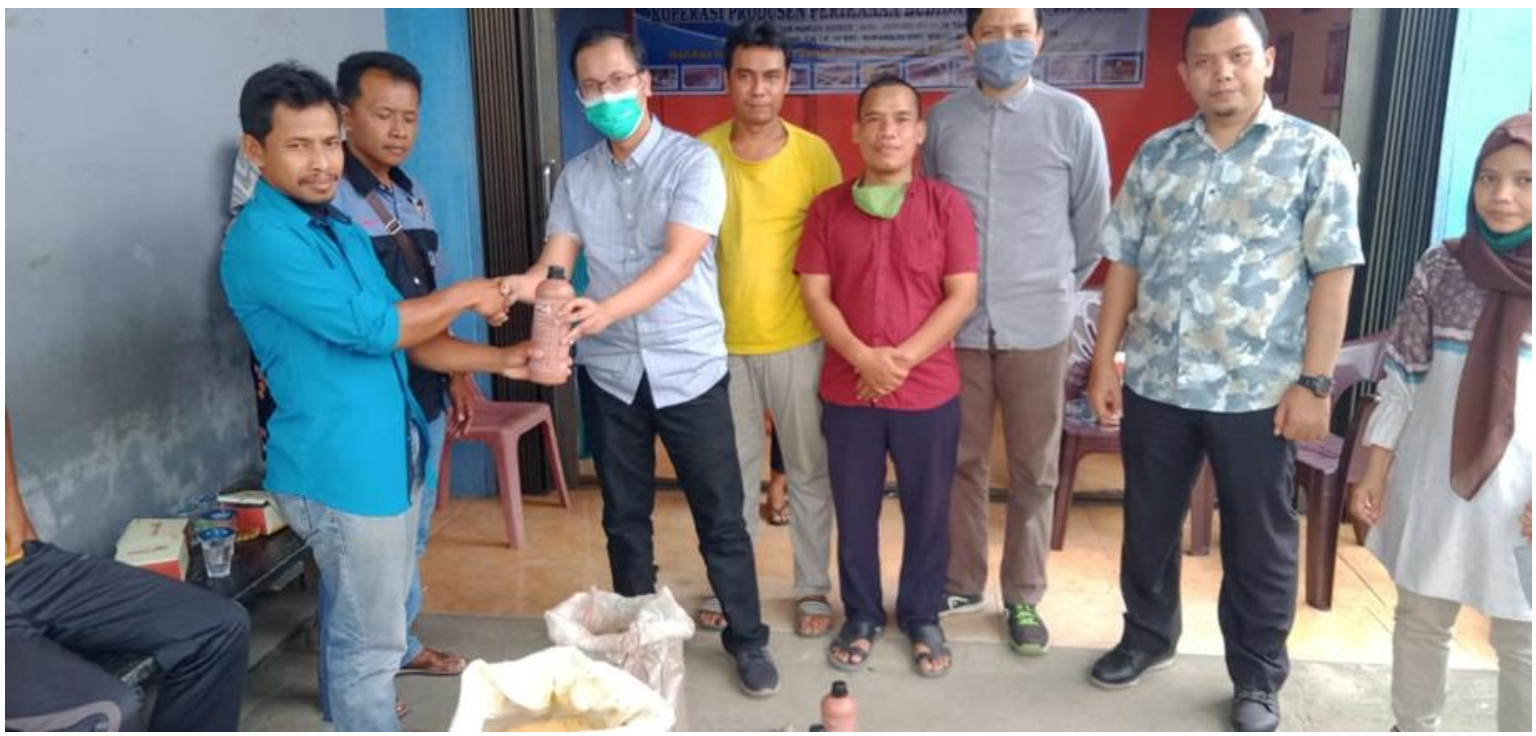

Gambar 3.3. Pelatihan Budidaya BSF (Black Soldier Fly) dan Penyerahan Bantuan dari Tim Pengabdian

Selain itu tim pengabdian menyarankan media lain untuk dijadikan media tumbuh maggot di tempat mitra agar tidak begitu memberatkan mitra kedepannya unntuk mengembangkan. Dimana tim pengabdian menyarankan pemanfaatan limbah organik seperti limbah sayur atau buah dan juga ampas tahu, dimana diketahui di sekitar mitra banyak industri pembuatan tahu.

\section{Kegiatan Pendampingan, Monitoring dan Evaluasi}

Kegiatan pendampingan terus dilakukan baik bertemu dengan mitra di lokasi mitra ataupun komunikasi via Whatsapp. Sampai saat ini belum ada kendala yang dihadapi pihak mitra. Selain itu juga dilakukan Monev oleh pihak Lembaga Pengabdian Kepada Masyarakat yang dilaksanakan pada tanggal 7 Desember 2020.

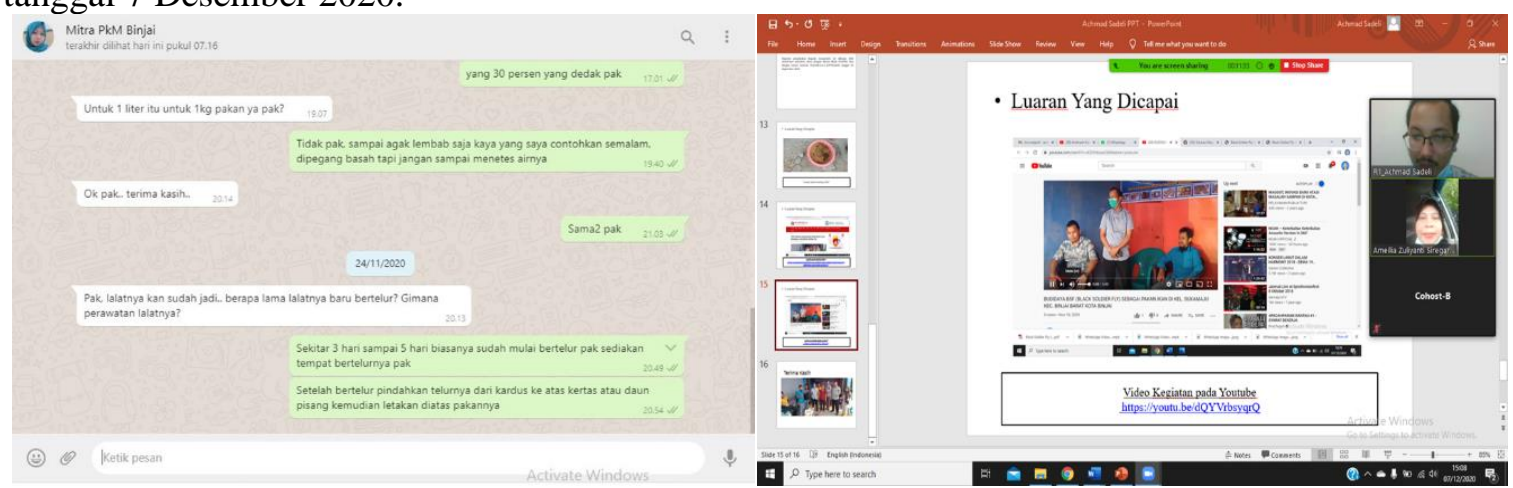

Gambar 3. 4. Komunikasi dengan Mitra Pengabdian dan Monev oleh LPPM USU

5. Luaraan yang dihasilkan 
Luaran yang dijanjikan tim pengabdian berupa artikel, produk, video dan media massa. Artikel akan di submit pada jurnal Abdimas Talenta. Produk yang dihasilkan berupa media tumbuh maggot (Gambar 5). Video yang dihasilkan sudah di upload pada youtube dengan alamat link https://youtu.be/dQYVrbsyqrQ dan media massa telah terbit secara online dengan link https://waspada.id/pendidikan/usu-edukasi-masyarakat-binjai-barat-cara-budidaya-lalat-blacksoldier-fly/.

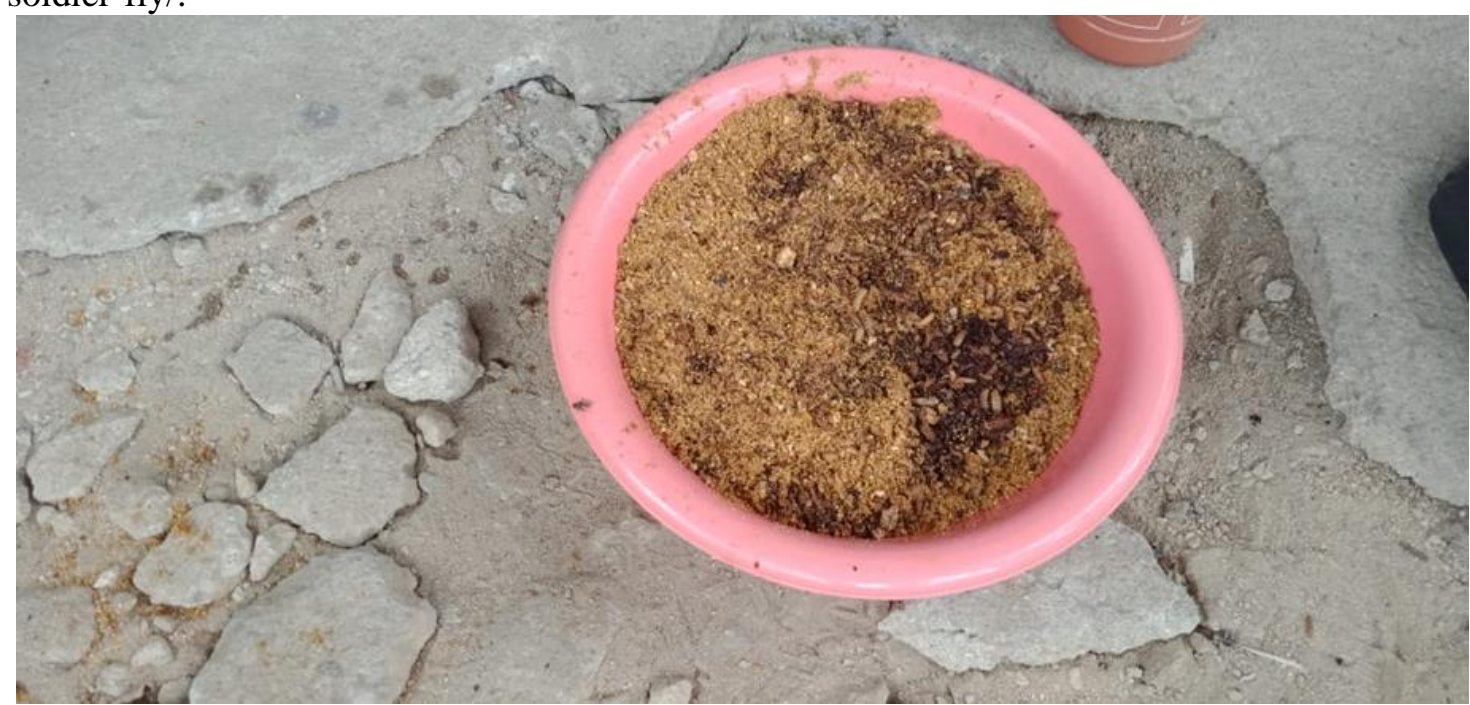

Gambar 3.5. Maggot dengan Media Dedak, Tepung Jagung dan Bungkil Inti Sawit

\section{KESIMPULAN (CONCLUSION)}

Dari kegiatan ini dapat ditarik beberapa kesimpulan:

1. Mitra mengetahui keunggulan BSF (Black Soldier Fly)

2. Mitra dapat membudidayakan BSF dengan baik dan benar, dengan memanfaatkan media dedak, tepung jagung, bungkil inti sawit dan juga limbah yang berada di sekitar mitra.

\section{UCAPAN TERIMAKASIH (ACKNOWLEDGMENTS)}

Terima Kasih disampaikan kepada Lembaga Pengabdian Kepada Masyarakat Universitas Sumatera Utara yang telah mendanai kegiatan ini melalui Skim Dosen Mengabdi dengan No Kontrak 754/UN5.2.3.2.1/PPM/2020 Tanggal 25 September 2020.

\section{DAFTAR PUSTAKA (REFERENCES)}

Badan Pusat Statistik, 2018. Kecamatan Binjai Barat Dalam Angka 2018. Katalog: 1102001.1276050. No: 12760.1806. Badan Pusat Statistik Kota Binjai.

Dinas Peternakan dan Kesehatan Hewan, 2015. Rencana Strategis (Renstra) Pembangunan Peternakan dan Kesehatan Hewan Provinsi Sumatera Utara Tahun 2013-2018. http://www.sumutprov.go.id/images/Er2017/Oktober/RenstraDisnakeswan_Sumut.pdf (Diakses: 2 April 2020)

M.Y. Abduh, M. Jamilah, P. Istiandari, S. Syaripudin and R. Manurung, 2017. Bioconversion of rubber seeds to produce protein and oil-rich biomass using black soldier fly larva assisted by microbes. Journal of Entomology and Zoology Studies, pp. 591-597.

Wardhana, A. P. 2016. Black Soldier Fly (Hermetia Illucens) sebagai Sumber Protein Alternatif untuk Pakan Ternak. Wartazoa. Vol. 26 (2), pp. 69-78. 